\title{
CAN INDIA EMERGE AS AN ALTERNATE HUB FOR CELL PHONE MANUFACTURING POST COVID 19?
}

\author{
Kaushal Buch $^{1}$,Vandana Sonwaney ${ }^{2}$ \\ ${ }^{1}$ Symbiosis Institute of Operations Management, Nashik, Symbiosis International (Deemed University), Pune, India \\ ${ }^{2}$ Professor, Symbiosis Institute of Operations Management, Nashik, Symbiosis International (Deemed University), Pune, India
}

\begin{abstract}
The COVID 19 pandemic outbreak has forced countries worldwide to undergo lockdown which in turn has brought economic stability to a standstill. The disruptions caused in the supply chain due to restriction of flow of material across countries has been a wakeup call for many countries for employing a de-risk manufacturing strategy and look for alternatives other than China by exploring various other promising countries. This research aims to understand the impact of COVID 19 on the global supply chain of cell phone manufacturing industry .The study gives an understanding on post COVID scenario of cell phone manufacturing industry in India considering the de-risk strategies employed by various countries. The research highlights the strengths and weaknesses of the current cell phone manufacturing industry, and also suggests key recommendations on the roadmap to emerge as the new manufacturing hub in near future.
\end{abstract}

Article Received: 10 August 2020, Revised: 25 October 2020, Accepted: 18 November 2020

\section{Introduction}

India has shown an incredible growth in cell phone manufacturing in the last decade and the "Make in India" campaign came in as a great catalyst. Owing to a prospective domestic demand and increase in exports over the years, India overtook US and emerged as the second largest mobile phone manufacturer in the world. India has a very prospective domestic market demand considering the fact that though the number of smartphone users have crossed 500 million by 2019, the smartphone users' penetration is just $36.7 \%$ [11]. With second largest population of mobile phone users and an exponential growth in exports i.e. $1537 \%$ since 2015 to 2019 , not only has India earned $2^{\text {nd }}$ position in most cell phones manufactured but also $12^{\text {th }}$ place in most cell phones exported. If India manages to grow even at same rate which is highly unlikely, India will be in top 5 list of most cell phones exported by the end of 2020.

As per the Economic Survey 2019-20, India can generate 80 million well-paid jobs in the next 10 years, by adopting strategy of 'Assemble in India for the world'. China has successfully become a manufacturing hub, owing to their vision of deliberately focusing on specializing in supply chains having large scale labour intensive involvement such as in "network products" which include the manufacturing of cell phones. But due to the US China trade war the scenario has changed in last few years, and India is emerging as a promising alternative.

The COVID 19 pandemic has forced various leading cell phone brands to look beyond China for prospective nations to setup their manufacturing facilities. This research paper is aimed to understand whether India can be the best alternative for the leading brands post COVID 19 by comparing the strengths and weaknesses with other alternatives such as Vietnam.

\section{Literature Review:}

Joonkoo Lee, Gary Gereffi and Dev Nathan in their paper "Mobile phones: who benefits in shifting global value chains?" [10] emphasised on how the cell phone manufacturing industry is very much driven by Global Value Chains (GVC). The developing countries have been able to extract the advantage of the same and have used the labour intensive attribute of the industry to attract most of the business and thus resulting in concentrated GVCs. Over three-quarters $(77.8 \%)$ of all mobile phones exported during 2019 were by suppliers in Asia, if we look through a continental perspective. China is the most dominant in manufacturing not only for the domestic market but also for global market, with $46 \%$ of total export.

China having most of the 13 major elements required for manufacturing of cell phone was quick to understand the requirement of GVCs in the cell phone manufacturing industry. China managed to build the infrastructure required for 
manufacturing and supply of mobile phones, of world class quality to the global market and thus was predominantly first mover in conceptualization of GVCs. The fact that china has the required material in abundance backed with world class technology resulted in concentration of GVC. Thus dependency on China increased immensely in early 2000s and is still very much prevalent.

India on the other hand is not so fortunate with availability of the required elements. Also with lack of visionary technological advancements, India was more focused on landlines and had lesser focus on development of technology and infrastructure for mobile phone manufacturing. But as the demand for smartphones has been increasing drastically from 76 million users in 2013 to 634 million in 2019 more and more foreign brands are setting up their manufacturing parts in India. Thus India has grown leaps and bounce to be a net exporter by 2019 and have $250+$ plants setup for manufacturing.

As per ICEA, the major factors for become a world leader in manufacturing of mobile phones are

1. Duty Differential

2. Export Incentives

3. Ease of Expansion of Manufacturing Capacity

4. Competitive Direct Tax Policy:

5. Labour Reforms

6. Ease of Doing Business

7. Effective Outreach Efforts

8. Design Ecosystem

Through the research the aim is to study how post COVID, India can improve on these factors to emerge as the best alternatives for the brands looking to move out of China, as a part of their de-risk manufacturing strategy. The study also highlights the key strengths and weaknesses of India with respect to other market leaders namely China and Vietnam.

\section{Research Methodology:}

The research is structured in the following manner:

1. Impact of COVID 19 on global supply chain

2. How has COVID 19 impacted Indian mobile manufacturing sector?

3. Can India emerge as an alternate manufacturing hub-SWOT Analysis

4. Roadmap and key recommendations

\subsection{Impact of COVID 19 on global supply chain}

The COVID 19 pandemic did not just impact psychologically but economically as well. The sectors which were hit hardest are the once relying on global supply chains. The companies which were over dependant on China had to experience profound implications initially with the factories being shut across china [6]. Not only did the companies having manufacturing facility in china but also the countries importing raw material for production suffered immensely due to the same.

The second quarter of 2020 saw a decline of $20 \%$ as per Gartner report [1] majorly due to the disruptions caused in the supply chain coupled with the buyer's choice of not directing the disposal income in buying cell phones.

\begin{tabular}{|c|c|c|c|c|c|}
\hline $\begin{array}{l}\text { Vend } \\
\text { or }\end{array}$ & $\begin{array}{l}\text { 2Q'20 } \\
\text { Units }\end{array}$ & $\begin{array}{l}\text { 2Q20 } \\
\text { Mar } \\
\text { ket } \\
\text { Shar } \\
\text { e }(\%)\end{array}$ & $\begin{array}{l}\text { 2Q'19 } \\
\text { Units }\end{array}$ & $\begin{array}{l}2 Q 19 \\
\text { Mar } \\
\text { ket } \\
\text { Shar } \\
\text { e }(\%)\end{array}$ & $\begin{array}{l}\text { 2Q'2 } \\
\text { 0- } \\
\text { 2Q'1 } \\
9 \\
\text { Grow } \\
\text { th } \\
(\%)\end{array}$ \\
\hline Others & $\begin{array}{l}97,692 \\
.1\end{array}$ & 33.2 & $\begin{array}{l}137,28 \\
2.5\end{array}$ & 37.1 & -28.8 \\
\hline $\begin{array}{l}\text { Samsu } \\
\text { ng }\end{array}$ & $\begin{array}{l}54,759 \\
.4\end{array}$ & 18.6 & $\begin{array}{l}75,111 \\
.8\end{array}$ & 20.3 & -27.1 \\
\hline $\begin{array}{l}\text { Xiao } \\
\text { mi }\end{array}$ & $\begin{array}{l}26,095 \\
.2\end{array}$ & 8.9 & $\begin{array}{l}33,250 \\
.7\end{array}$ & 9.0 & -21.5 \\
\hline OPPO & $\begin{array}{l}23,612 \\
.1\end{array}$ & 8.0 & $\begin{array}{l}28,070 \\
.2\end{array}$ & 7.6 & -15.9 \\
\hline $\begin{array}{l}\text { Huaw } \\
\text { ei }\end{array}$ & $\begin{array}{l}54,125 \\
.0\end{array}$ & 18.4 & $\begin{array}{l}58,055 \\
.7\end{array}$ & 15.7 & -6.8 \\
\hline Apple & $\begin{array}{l}38,386 \\
.1\end{array}$ & 13.0 & $\begin{array}{l}38,522 \\
.9\end{array}$ & 10.4 & -0.4 \\
\hline Total & $\begin{array}{l}294,66 \\
9.9\end{array}$ & 100.0 & $\begin{array}{l}370,29 \\
3.9\end{array}$ & 100.0 & -20.4 \\
\hline
\end{tabular}

Subsequently, COVID outbreak has resulted in widespread disruptions in supply chains due to overdependence on China and thus there are talks that companies are considerate of reducing their dependence on China and exploring possibilities of de-risking. This gives an opportunity to other nations to further develop the ecosystem of mobile manufacturing in their country and pull the share of business in their favour. Recently many countries as a part of de-risk manufacturing strategy have allocated economic stimulus packages. Japanese Government came out with an aggressive economic stimulus package of US\$ 2.2 
billion to assist its manufacturers in shifting production from China. This aggressive step was as a result of dry patch that Japanese manufacturers faced due to supply chains disruptions between the major stakeholders. Wellknown electronics manufacturers such as Wistron, Foxconn and Pegatron are mulling diversification/increase of production facilities outside of China.

These factors provide India a great opportunity for projecting itself as a promising alternative location for manufacturing mobile phones. India can exploit this opportunity by employing the proactive policy initiatives in order to attract leading global firms. India faces a fierce challenge from countries such as Vietnam, Thailand, Indonesia and Malaysia as they are offering attractive economic incentives, superior tax brackets and infrastructure to multinational firms for attracting more foreign investments in their countries. In March 2020, India came up with a trilogy of schemes [7] of the nature of production linked incentives that are WTO compliant. Such type of schemes are in the pipeline or execution in other countries as well and thus the success of such schemes will rely more so on effective implementation. The disbursement process also will play a pivotal role in making the schemes beneficial in longer run.

\subsection{How has COVID 19 impacted Indian mobile manufacturing sector? \\ a. Projected growth takes a hit:}

India is the largest market for handsets after China. The sale of smartphones in 2019 increased by $12 \%$ and projections about a $14 \%$ increase in 2020 were made. COVID 19 has forced closure of manufacturing units of all the brands across India and thus the sales projections had a huge hit. According to Counterpoint Research, the lockdown imposed in phases might result in a USD 2 billion hit for the smartphone industry in India.

Prabhu Ram who is heading the industry intelligence group of CMR has said that they are keeping a close tab on the macroeconomic factors and how the industry will play from here. In the best-case scenario there will be a decline of about $11 \%$ in overall smartphone shipments for this year.

According to Gartner report (August 2020), India which adopted several lockdowns logged one of the worst decline in sales of smartphone $(-46 \%)$ amongst other countries in the world in the second quarter.

\section{b. Disruptions in supply and demand:}

Owing to the speculation that the virus originated from China combined with the recent tension with china along the border because of the aftermath of the June 15 Galwan Valley clash, a sentiment of 'boycott Chinese products' has emerged. Chinese brands such as Xiaomi and Oppo faced the heat regarding the same via protests outside their factory premises. But most of the Indians are unaware of the fact that though India manufactures the most mobile phones after china, but is very much dependent on china for the supply of most of the key components used in making phone.

The dependency on China for the supply of various key components has caused the biggest disruption for India in this sector as the trade between the two nations was hugely impacted due to the pandemic.

While the cell phone manufacturers fight the supply chain issues due to the high dependency on China at one end, they are also facing drop in demand as the disposable income of people took a hit due to the pandemic.

\section{c. Promising signs in unlock phases:}

Though the cell phone companies struggle to handle the disruptions caused in supply and demand in such volatile scenario, the unlock phase has been showing some positive signs especially in the low end markets. The demand for the low end market, typically under ten thousand rupees, has been showing growth over the last two months. The forced scenario of online education, work from home, online purchase has made smartphones critical and essential commodity.

It is said that Samsung has been the worst-hit company in India's smartphone market. The share of Samsung smartphone in the market Dropped by $16 \%$ in the first quarter. Samsung is facing a lot of competition from Chinese companies. Vivo grew by $45 \%$ and became the second-largest brand of the smartphone market in India with a $17 \%$ market share. Samsung has partnered with technological companies to launch a new digital platform so that customers can buy Samsung smartphones online from local retailers. 
4. SWOT Analysis

\begin{tabular}{|c|c|c|}
\hline & $\begin{array}{l}\text { Helpful } \\
\text { In achieving the objective }\end{array}$ & $\begin{array}{l}\text { Harmful } \\
\text { In achieving the objective }\end{array}$ \\
\hline 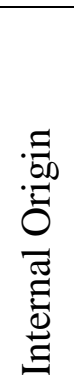 & $\begin{array}{l}\text { 1. Low labour wages } \\
\text { 2. Growth in young working } \\
\text { population } \\
\text { 3. Strong domestic customer } \\
\text { base } \\
\text { 4. PLI scheme for attracting } \\
\text { foreign investors }\end{array}$ & $\begin{array}{l}\text { 1. Higher cost of production viz-a- } \\
\text { viz China and Vietnam } \\
\text { 2. Lack of technology to make } 100 \% \\
\text { made in India product. } \\
\text { 3. Lack of Indian brands }\end{array}$ \\
\hline 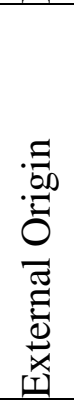 & $\begin{array}{l}\text { 1. Geopolitical issue } \\
\text { (Trade war-US China) } \\
\text { 2. Electronics import is ranked } \\
\text { in top 5 most imported } \\
\text { products } \\
\text { 3. De risk manufacturing } \\
\text { strategy by various nations }\end{array}$ & $\begin{array}{l}\text { 1. Well Established Exporter- } \\
\text { Vietnam }\end{array}$ \\
\hline
\end{tabular}

\subsection{Strengths}

\section{a. Low labour wages:}

The cell phone manufacturing company involves various automated process but is still very much a labour-intensive manufacturing process owing to assembly of various components. China and Vietnam have been key players in cell phone manufacturing so far but as per International Monitory Fund 2019 [5], the per capita GDP of
China is 10,099 USD and that of Vietnam is 2740 USD.This makes India's per capita GDP lowest at 2172 USD, thus labour in India is cheapest among the three and the trend is expected to continue.

This gives India an unparalleled opening for luring in the mobile manufacturing companies to make mobile phones in India and import it to other parts of the world and in the process may employ millions of workforce.

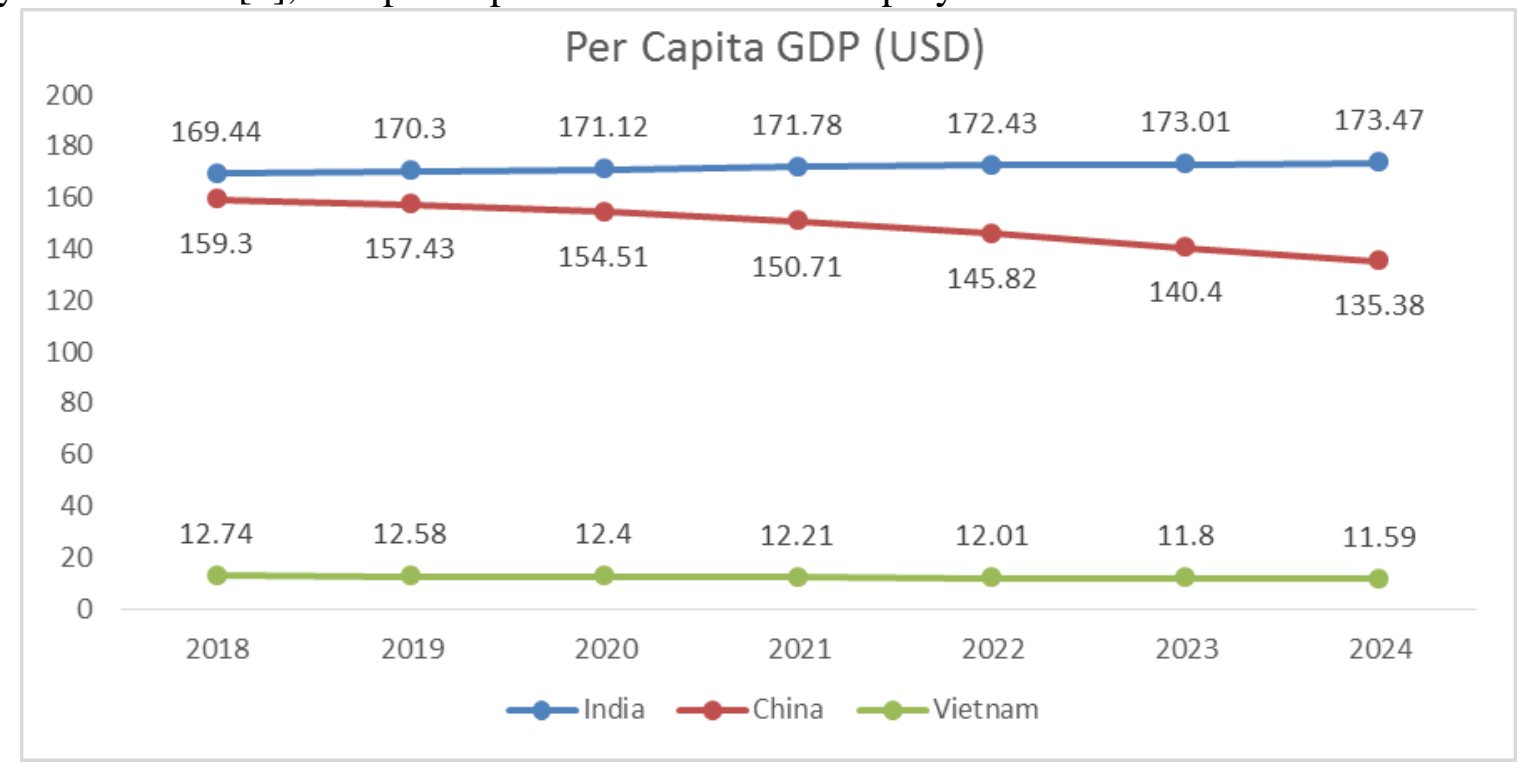




\section{b. Growth in workforce:}

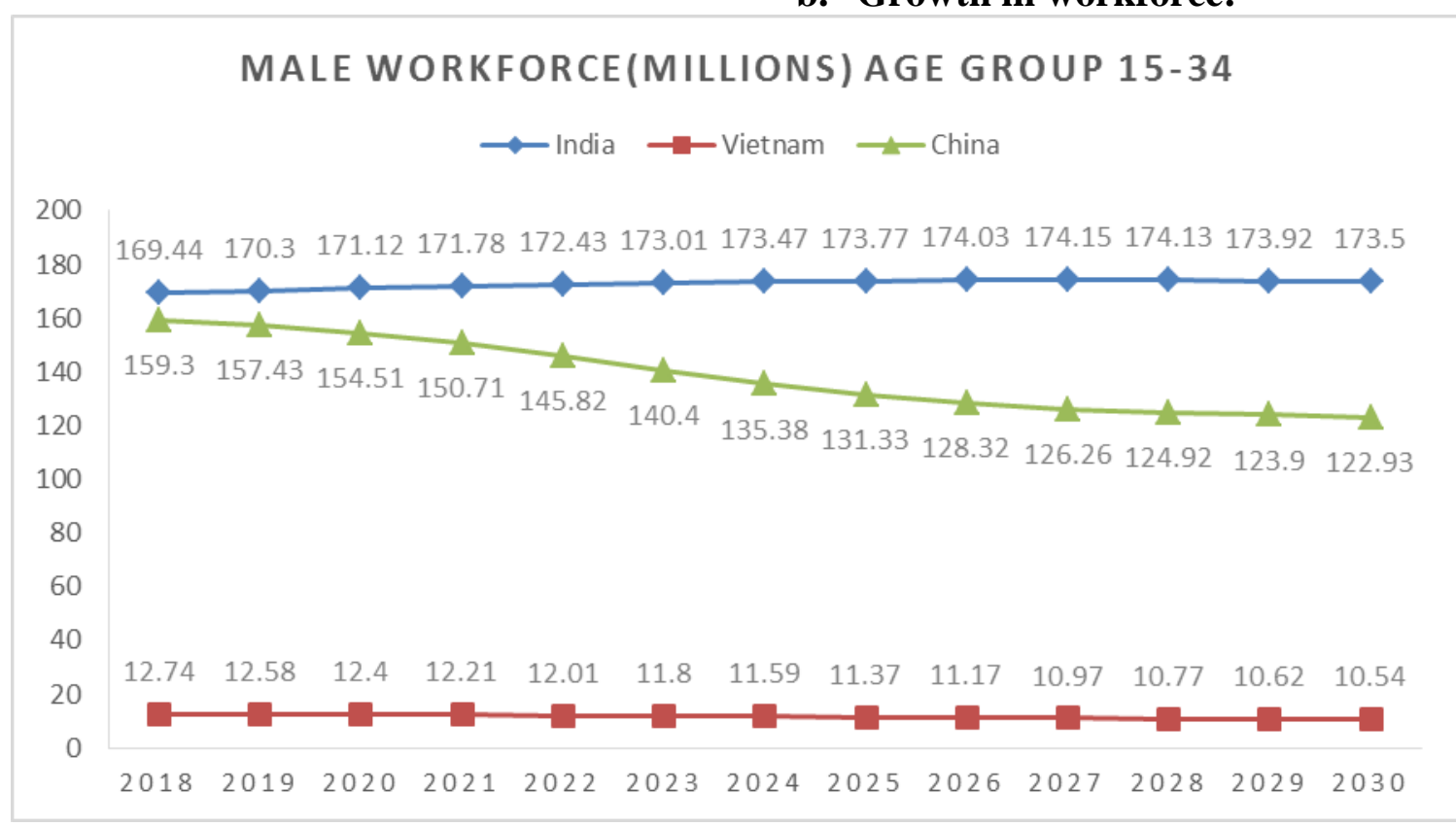

\section{c. Strong domestic customer base}

India is just behind China in terms of largest user base for smartphones in the world. With digitalization of supply chain now more inevitable than ever before and growth in the young demographics of India the growth of smartphone users is on the rise.

\section{No. of Smatphone Users-India}



Thus not only the export scenario but also the domestic demand looks very promising, which will help in attracting more foreign brands. Though the goal of India should be to focus on make in India for the world, but once the foreign brands are tapped we can eventually expect them to cater to both domestic and global market, like the recent example of Samsung in past 2 years.

d. PLI scheme for attracting foreign investors
The National Policy on Electronics 2019 (NPE 2019) was formulated for positioning India as hub for Electronics System Design and Manufacturing (ESDM) globaly.This vision can only be achieved by striving forward in the direction of developing core components and more importantly developing an ecosystem for the industry to compete with other world class manufacturing ecosystems of the world.

Under the same vision government has come up with Production Linked Incentive Scheme 
(PLI) in the electronics manufacturing sector specifically for large scale production units. Through this scheme the idea is to boost domestic manufacturing by offering a production linked incentive, this will also attract large foreign investments via leading players of mobile phone manufacturing sector which will then result in more Assembly, Testing, Marking and Packaging (ATMP) units.

The idea behind the scheme is mainly to encourage manufacturing of goods in India for targeted segments by providing incentives in the range of $4 \%$ to $6 \%$.The incentives will be on incremental sales (over base year) for certain eligible companies for a period of five (5) years.

Under the umbrella of PLI scheme the road map is to outlay 50,000 crore rupees through schemes such as Scheme for Promotion of Manufacturing of Electronic Components and Semiconductors (SPECS) and Modified Electronics Manufacturing Clusters (EMC 2.0) .

The concerned ministry of the government has said that these three schemes is expected to increase the production of cell phone components and cell phones by attracting substantial investments and thus increase the revenue generation to almost one lakh crore by 2025 . This will also benefit in generating five lakh direct and fifteen lakh indirect jobs.

As per the report of ICEA, since the inception of the scheme various companies like Wistron, Foxconn, Lava, etc. have promised investments worth Rs.11,000 crore which will result in manufacturing 2 to 2.5 times more than estimated numbers.

Thus successful implementation of these schemes will not only attract foreign brands but also help develop the technological ability of India which will help India emerge as a global manufacturing hub for mobiles.

\subsection{Weakness :}

\section{a. High Manufacturing cost with respect to} China and Vietnam:

In order to be competitive in terms of cost with respect to other countries, there are several factors that can help reduce the cost of manufacturing.

From a report published by ICEA [2], the comparison of how India fair with respect to China and Vietnam is as shown under:

\begin{tabular}{|c|c|c|c|c|}
\hline $\begin{array}{l}\text { S. } \\
\text { No } \\
\end{array}$ & Factor resulting in cost-reduction & India & China & Vietnam \\
\hline 1 & R\&D subsidy & $0.15 \%$ & $2 \%$ & $0.4-1 \%$ \\
\hline 2 & $\begin{array}{ll}\text { Corporate income } & \text { tax } \\
\text { exemption/reductions }\end{array}$ & $0.73-0.95 \%$ & $2 \%$ & $1.5-2 \%$ \\
\hline 3 & Subsidy for machinery and equipment & Nil & $3 \%$ & $0.2 \%$ \\
\hline 4 & Incentive for supporting industry & Nil & Nil & $0.5-1 \%$ \\
\hline 5 & State subsidies for capital investments & $0.6-1.2 \%$ & NA & NA \\
\hline 6 & Interest subvention on working capital & Nil & $3-3.5 \%$ & $1.5-2 \%$ \\
\hline 7 & Cost of power & Nil & $1 \%$ & $1 \%$ \\
\hline 8 & Exemption/reduction of land rental & Nil & $0.60 \%$ & $0.5 \%$ \\
\hline 9 & Logistics & Nil & $1 \%$ & $0.5 \%$ \\
\hline 10 & Industrial land development support & $0.4 \%$ & $0.60 \%$ & $0.5 \%$ \\
\hline 11 & Labour subsidy Negligible & Negligible & $2 \%$ & $0.5 \%$ \\
\hline 12 & Building (or plug and play) & Negligible & $1 \%$ & $0.3 \%$ \\
\hline 13 & $\begin{array}{l}\text { Duty free imports in order to create fixed } \\
\text { assets }\end{array}$ & Nil & Nil & $0.5 \%$ \\
\hline 14 & Factors effecting "Ease of doing business" & Nil & $2-3 \%$ & $1.5-2.5 \%$ \\
\hline 15 & Production-Linked Incentive Scheme & $\begin{array}{l}4-6 \% \text { of } \\
\text { FOB value } \\
\text { of exports }\end{array}$ & $1-2 \%$ & $0 \%$ \\
\hline Tota & & $5.88-8.7 \%$ & $\begin{array}{l}19.2 \%- \\
21.7 \%\end{array}$ & $9.4-12.5 \%$ \\
\hline
\end{tabular}


As evident in the above table manufacturers in China and Vietnam are almost $15 \%$ and $5.8 \%$ more cost competitive as compared to India and thus even if companies try and diversify Vietnam might seem to be a more lucrative option.

\section{b. Lack of technology to make $100 \%$ made in India product}

The key components in making mobile phone are mainly circuit board, display, speaker, sim card holder, microphone, antenna, monitor battery, etc.

China and Vietnam have the infrastructure and technology for manufacturing all the components and assemble and thus they have been very competitive over the years.

On the other hand, India currently is more sort of an assembly hub with the key components like circuit board, display, etc. are imported from China, Taiwan and several other countries.

Though strategic government policies have forced the manufacturers to graduate from SKD (Semi Knocked Down) type to CKD (Complete Knocked Down) type and thus several local suppliers manage to supply the small parts such as speaker, buzzer, vibrator, antenna, etc.

Thus in order to increase the value addition and to manufacture mobile phones completely from scratch, India is still far behind China and Vietnam and needs a long strategic path ahead.

\section{c. Lack of Indian Brands}

The performance of Indian brands such as Lava and Micromax took a huge hit with low end products of Chinese make like Xiaomi, Oppo, and Vivo sweeping the market in 2018.

The advantage of Indian brands is the employment and business it brings to the local companies and there by the benefit to India overall is high.

While foreign brands have their own contract buying of certain key components from various other nations thus the benefit to India gets limited.

\subsection{Opportunity}

\section{a. Geopolitical issue(Trade war -US China)}

The trade war begin in May 2018 with United States announcing tariffs on goods imported from China effective 6 July 2018[4]. In retaliation China imposed tariffs as well. Trade war intensified further with subsequent tariff rates imposition in September 2018, June 2019 and September 2019. India could not capitalize on the trade war back then with Vietnam and Taiwan taking the opportunity to export to the US. There are further discussions going on between US and China to revise the tariff rates and this time India is in much better pace with attractive PLI schemes.

\section{b. Electronics import is ranked in top 5 most imported products}

The electronics industry is growing at a brisk rate [3] and most countries are dependent on global value chains for the same which is evident by the fact that electronics import is ranked in top 5 most imported products. This presents a great opportunity for countries like India.

Thus India should capitalize upon the development prospects of the industry and channelize their strategy and resources to serve the import requirements of other nations.

\section{c. De risk manufacturing strategy by various nations}

India like many countries across the world is hit hard by the pandemic. Various leading brands of mobile phone where hit hard due to the supply chain disruptions caused, especially due to over dependency on china.

Countries have initiated the move to de risk manufacturing with countries like Japan announcing package of 536USD to move out 57 companies from China. [9]

Similarly major brands like Samsung who now does not have a single manufacturing facility in China are looking towards India as the best alternative.

\subsection{Threat \\ a. Established exporter-Vietnam}

By 2019, the mobile phone export of Vietnam reached 63.10 billion USD from 6.68 billion USD in 2011[8].Thus the required policies and infrastructure for world class export is already in place. On the other hand, India became a net exporter just in 2019. India managed to export 3.2 billion USD of cell phones in 2019.Thus India has a tough challenge from Vietnam, especially in global market.

\section{Key Recommendations:}

\section{a. Strengthen the ecosystem with schemes such as PLI:}

The government needs to strengthen the ecosystem for electronics in India by replicating the PLI scheme with suitable changes. India lags in technological development and depends on other nations for certain parts thus in order to overcome the same, India must target to develop 
areas of core technology and at the same time work for broadening component ecosystem.

In order to develop a sustainable ecosystem it is important to have a deeper engagement with the industry in order to understand the handful core technologies. At the same time, schemes steering component manufacturing requires microscopic review to aptly draw attention on components that will not only strengthen mobile manufacturing industry in India but also prove to be definitive factor in drawing greater portions of global supply chain in India.

\section{b. Improve the cost saving factors}

PLI scheme by the centre helped India close the gap on manufacturing cost, but still the gap remains as wide as fifteen percent and five percent with China and Vietnam respectively.

India can improve on various contributing factors such as subventions on working capital, land and labour subsidy, interest, land rentals, etc. The factors need to be worked upon individually by the combined effort of state and centre, just like PLI scheme.

\section{c. Policy Restructuring:}

A broad review and revamp of India's taxation policies, which include a review of GST, duties under PMP and other taxes that impede the pace of exports from India is critical in making India a global hub for electronic manufacturing.

India needs to not only encourage local companies to come up with innovative ideas to reduce the dependency on other nations but at the same time attract foreign investors and this balance needs to be maintained for the coming years by fine tuning the tax structure so that both the local and global players are nurtured.

\section{d. Successful implementation of PLI scheme:}

The success of the PLI Scheme will be completely dependent on the guidelines being competitive, practical and disbursement being timely. Currently as per the guideline, the applicant will be getting reimbursement in for of direct bank transfer. On a trial basis MEIS-type disbursement can be tested which can assist the manufacturers by providing much needed liquidity in the form of cash may be against some sort of duty scrips.

\section{Conclusion}

India enjoys the status of being the second largest producer of cell phone in the world, only behind china. But majority of the manufactured cell phones are catering the domestic market. In terms of export India is currently at the $12^{\text {th }}$ position and expected to reach top 5 by 2022. China caters almost $47 \%$ of the global demand through exports and Vietnam is second with $13.3 \%$. India in the wake of the pandemic has announced PLI scheme which can help India attract various foreign brands to make in India for the world. Currently the gap between India and China is too huge but the kind of growth India has shown since 2014 through make India is remarkable. In terms of the SWOT analysis, India looks to be on the right track to emerge as an alternative manufacturing hub after China, if it manages to attract foreign brands through PLI and embarks on the journey of self-reliant supply chain.

\section{References}

[1] https://www.gartner.com/en/newsroom/pres s-releases/2020-08-25-gartner-says-globalsmartphone-sales-declined-20--in-

[2] Report titled "Making India a global hub for handset manufacturing" by ICEA

[3] https://www.jeita.or.jp/english/topics/2018/1 218.pdf

[4] https://www.nytimes.com/2018/07/05/busin ess/china-us-trade-war-trump-tariffs.html

[5] https://www.imf.org/external/datamapper/N GDPDPC@WEO/OEMDC/ADVEC/WEO WORLD

[6] https://www.weforum.org/agenda/2020/02/c oronavirus-economic-effects-globaleconomy-trade-travel/

[7] https://meity.gov.in/esdm/pli; https://meity.gov.in/esdm/SPECS; https://meity.gov.in/esdm/emc 2.0

[8] https://www.trademap.org/Product_SelCoun try_TS.aspx?nvpm $=1 \% 7 \mathrm{c} 704 \% 7 \mathrm{c} \% 7 \mathrm{c} \% 7 \mathrm{c}$ $\% 7 \mathrm{c} 85 \% 7 \mathrm{c} \% 7 \mathrm{c} \% 7 \mathrm{c} 4 \% 7 \mathrm{c} 1 \% 7 \mathrm{c} 1 \% 7 \mathrm{c} 2 \% 7 \mathrm{c} 2$ $\% 7 \mathrm{c} 1 \% 7 \mathrm{c} 1 \% 7 \mathrm{c} 1 \% 7 \mathrm{c} 1$

[9] https://www.bloomberg.com/news/articles/2 020-04-08/japan-to-fund-firms-to-shiftproduction-out-of-china

[10] https://www.researchgate.net/publication/2 56063450_Mobile_Phones_Who_Benefits_i n_Shifting_Global_Value_Chains

[11] https://www.statista.com/statistics/257048/ smartphone-user-penetration-in-india/ 